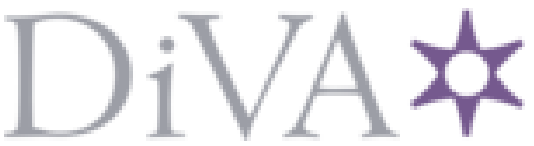

http://www.diva-portal.org

Preprint

This is the submitted version of a paper published in Scandinavian Economic History Review.

Citation for the original published paper (version of record):

Lindmark, M., Olsson Spjut, F. (2018)

From organic to fossil and in-between: new estimates of energy consumption in the Swedish manufacturing industry during 1800-1913

Scandinavian Economic History Review, 66(1): 18-33

https://doi.org/10.1080/03585522.2017.1401554

Access to the published version may require subscription.

N.B. When citing this work, cite the original published paper.

Permanent link to this version:

http://urn.kb.se/resolve?urn=urn:nbn:se:umu:diva-141949 


\title{
From Organic to Fossil and in between. New estimates of energy consumption in the Swedish manufacturing industry 1800 to 1913.
}

\author{
Magnus Lindmark (corresponding author) \\ Department of Geography and Economic History \\ Center for Environmental and Resource Economics (CERE) \\ Umeå University, Sweden \\ e-mail: magnus.lindmark@umu.se \\ tel: $+46(0) 702070510$
}

Fredrik Olsson Spjut

Department of Geography and Economic History

The Centre for Regional Science (Cerum)

Umeå University, Sweden

This is an Author's Original Manuscript of an article published by Taylor \& Francis Group in

Scandinavian Economic History Review, 2018. Available online:

https: //www.tandfonline.com/doi/full/10.1080/03585522.2017.1401554

\section{Acknowledgements}

The research was supported by Stiftelsen Riksbankens Jubileumsfond through the project "The limits to growth in a sustainable society: Energy use and area requirements in early modern Sweden". Dnr P10-0701:1 and Jan Wallanders och Tom Hedelius Stiftelse Tore Browaldhs Stiftelse "Engines for sustainability. Horsepower prices, capital substitution and energy transitions in the long run" 
The role of energy in the British industrial revolution and in subsequent industrialization processes in other countries is one of the central themes in economic history (i.e. Wrigley 1962; Cipolla 1964; Wilkinson 1973; Malanima 2016). Energy supply, and especially so the access to easily extractable coal in England, was also a cornerstone in Kenneth Pomeranz' (2000) explanation of the great divergence. It is fair to say that the debate within economic history on the role of fossil energy has much to owe the writings of Tony Wrigley $(1962,1988,2010,2016)$, who, in his interpretation of the industrial revolution, stressed the importance of a transition from an organic energy system to a mineral energy system, the former based on photosynthesizes and the latter based on fossil fuels. In short, Wrigley argued that the scale of energy flows in the organic energy system are ultimately limited by the arable acreage. This is so since photosynthesizes, the bio-chemical, solar energy based process by which plants transform atmospherical carbon dioxide to carbon hydrates and cellulose, the fabric of plants, is depending on land. Photosynthesizes was therefore the basis for most energy flows in the organic energy system, including fuels for industrial and domestic purposes along with nutrition for humans and draught animals. There is also an economic theoretical side to the argument. Real capital employed in manufacturing required energy - not the least in the form of fuels - in order to provide a flow of capital services and ultimately a flow of capital-income. This implies complementarity between capital and energy. Another way of putting it is that energy demand is derived from the demand for capital. This is important since several studies point at capital deepening, the increase of capital intensity of labor, as a basic factor behind economic growth (Allen 2012; Atack 2005). A strong complementarity exists between capital and energy if the two are subject to joint demand, or even more specifically, if energy demand is derived from the demand for real capital. This is indeed likely and the standard approach taken by contemporary energy economists. In short, this implies that if demand for real capital increased in the organic economy, this demand would have tended to induce a more or less proportional increase in energy demand. As the potential energy supply in the organic economy was nonetheless limited by the land area, this limitation would have manifested itself in a low price-output elasticity of energy. Even if energy prices tended to increase as real capital formation drove up demand, the scope for the market to respond with an increased output was restricted. Higher energy prices would in turn have caused diminishing returns on the initial real capital investments, causing the growth process to grind to a halt. According to Wrigley's hypothesis this was only off-set with the emergence of the mineral energy system. As coal was not limited by land area, the price elasticity of energy increased, implying that energy supply ceased to function as a major cause of diminishing returns. This proposed causality motivates studies into how the transition to a mineral energy system unfolded not only in Britain, but also in other countries to which the industrial revolution was diffused.

This article presents new estimates of energy consumption in the Swedish manufacturing industry during the period 1800 to 1913 , thus covering the industrialization phase of the country. This is not trivial since the previous estimates of this sector where made with the primary intention to be used for value added estimates in the Historical National Accounts. This means that some significant parts of the energy consumption, relevant for a pure energy account, were left out (Schön 1988). As there are no monetary transactions for the service flow of mechanical hydropower, it is perfectly correct to leave this input in a Value Added calculation. However, it is also clear that the estimates of industrial energy inputs in Schön (1990) must have left out important items, not the least energy use at various intermediate production stages in the iron industry. It is in all cases not possible to exactly evaluate 
the series since the documentation on how the series were constructed were never published. As pointed out by Jørgen Peter Christensen (1994), discussing the Danish historical accounts, failure to do so causes problems both when trying to evaluate the quality of the series and when trying to revise existing series. With new estimates we can deepen the understanding as to how the transition from the organic energy system to a mineral based energy system unfolded in Sweden. Since Sweden is a country which in essence lack domestic coal reserves, and therefore was unable to undertake a transformation of its energy system without foreign trade, it adds to the general narrative and understanding of the industrialization process, understood as the spatial diffusion of the industrial revolution. By focusing the manufacturing industry we can reduce the uncertainties induced on the national level by unreliable energy consumption estimates for the household sector during the period. We will therefore discuss the household energy consumption, not as a criticism of previous models, but as a way to initiate a debate on how to approach the problem of missing data in this sector. In addition, the article also presents estimates of coal consumption in the energy sector, foremost gasworks, and in the transportation sector. Accordingly, the purpose of the article is to explore how the energy consumption developed in the economic sectors that drove the Swedish industrialization. The questions addressed in the article are:

How did energy consumption and energy intensity develop in Swedish manufacturing over the period?

(2) To what extent was coal linked to the leading sectors, manufacturing and transportation, during the Swedish industrialization?

(3)

To what extent does manufacturing industry affect the aggregated primary energy use.

A first motivation for revisiting the energy consumption estimates for the Swedish manufacturing industry, originally constructed by Lennart Schön (see Kander's 2002) seems to have omitted energy estimates for certain firewood consuming activities, foremost iron manufacturing, charcoal production and tar production. As previously pointed out we cannot be sure whether this was due to the fact that Schön's original energy series were constructed with historical value added estimates in mind, which makes it superfluous and even erroneous to account for intermediate inputs for the production of goods that are intermediate inputs themselves, of if other considerations have been of the essence. In all cases, it is motivated to recalculate the energy inputs all over again. Kander has presented adjustments of Schön's original estimates (Kander et al 2017) using a different approach as compared to the one taken in this article. A final motivation concerns the role of coal as a household fuel. Besides Kander's (2002) bench-mark estimates for 1850 and 1870 there have been no attempts to construct annual time series which separate between intermediate and final consumption of coal in the Swedish nineteenth century economy. In other words the aggregate time series estimates of coal consumption do not distinguish between coal used for domestic heating purposes, and this being an item on the consumption side of the economy, and coal used in boilers and steam engines, and accordingly being an item on the production side of the economy. As we will demonstrate in the article, such a distinction is important since intermediate coal consumption was linked to the mechanization of manufacturing and transportation services, both regarded as key sectors in the industrialization process. This article presents new estimates of the energy consumption in the Swedish manufacturing industry, with the aim to re-examine whether Sweden followed an industrialization path which in energy terms resembled the general Western European pattern, with a pronounced increase of coal consumption, or if the pattern reported for Finland (Kunnas \& Myllyntaus 2009), an industrialization based on organic energy sources had indeed been preceded in Sweden. The article therefore focuses new estimates of (1) the amount of firewood 
consumed in the charcoal making process, (2) firewood consumption and other wood fuels in other industries than iron industry before 1913 (3) the amount of charcoal used in the process of turning pig iron into bar iron before 1871 and (4) an estimate of the coal consumed in the manufacturing and transport sectors. Please notice that we do not make any attempts to estimate neither draught animal nor human energy in the manufacturing sector. The reason for not including draught animals is the lack of reliable historical sources, which only provides data on the national level. In the case of human energy it is addition a complex problem from an accounting perspective. This is so since compensation to labor, gross wages, is already included as one of the two major components in GDP. Considering the wage as the hiring cost for labour, this cost already includes the food stuffs necessary for providing physical labor. One important consideration in this context is that the value per energy unit is considerable higher concerning foodstuffs as compared to fuels, which has an impact on energy cost shares if the items are aggregated. Since foodstuffs and fuels are not close substitutes, one do not fire a steam engine with wheat, it is not self-evident that the two should be aggregated into one factor of production. Exactly how this problem should be solved, while still maintaining the national accounting identities which underpins the GDP measure and the concept of economic growth, is not subject for further consideration in the article.

\section{Reconstructing energy series for the Swedish manufacturing industry}

\subsection{Firewood consumption in the iron industry}

Iron and copper production were important sectors in the Swedish economy already from the medieval period (Hildebrand 1992, p. 17). It is a well-established fact that the iron industry consumed significant amounts of charcoal. One exponent of the high energy consumption were the strict regulations of the iron industry, introduced from the 1630s. Apart from being part of a the mercantilist policy of the era, these regulations served the purpose of managing the strategically important forest resources needed for the fuel supply at various stages of metal smelting and processing of iron and other metals (Hildebrand 1992, p 119-123). Other exponents of the high energy consumption at the iron works were reports of forest shortages during the mid-18th century (Kandell 1988; Sundberg 1992). Whether the reports reflected overly low administrated prices, failing to induce a higher supply or charcoal, or if the reported shortages were indeed due to a physical shortage of wood was debated in the 1930's, without any firm conclusions being reached (Wieslander 1936). In all cases, all stages of the iron making process required significant amounts of firewood and charcoal. Fire-setting was the standard method used in mining and it remained so until the introduction of explosives in the early nineteenth century (Hildebrand 1992). This means that it is not necessary to estimate firewood consumption in fire-setting during the period studied here. The three remaining iron production stages; roasting to enrich the ore, smelting for producing pig iron and finally the manufacturing of bar iron did, however, require substantial amounts of charcoal. The main source for the charcoal consumption in the iron industry is Gunnar Arpi (1951) who stated a consumption of $417 \mathrm{hl}$ (hector litres) of charcoal per ton of bar iron in 1825. Note that the estimates by Arpi included charcoal consumption also in the manufacturing of pig iron. The fuel intensity was, however, reduced due to technological developments during the nineteenth century. The most important technologies were the Bessemer and Martin processes which by the year 1900 had reduced the fuel requirements to $129 \mathrm{hl}$ of charcoal per ton of bar iron. For the period before 1825 we use a benchmark by John Svidén $(1996$, p. 53), who states a charcoal intensity of $525 \mathrm{hl}$ per ton in the year 1700. Here, we have assumed a linear interpolation between 1700 and 1825, while we are only using the figures for 1800 to 1825 in this study. In the present study, we have departed from the diffusion of improved smelting technologies in order to estimate the effects on the charcoal intensity 
from the 1850s and onwards (Olsson 2007, 34-35). To estimate the total charcoal consumption in hl we have multiplied the intensities with estimates of the total bar iron output (Olsson 2007, appendix 4). The transformation of charcoal consumption in $\mathrm{hl}$ to tons is based on Klason (1919) who stated a density of charcoal at $13 \mathrm{~kg}$ per $\mathrm{hl}$. This was necessary for the transformation from $\mathrm{hl}$ to coal equivalents. To reach a final estimate of the primary energy inputs, which includes the energy needed for producing the charcoal, we have assumed $0.12 \mathrm{~m} 3$ of wood for the production of one $\mathrm{hl}$ of charcoal (Arpi 1951, p 33). The energy content of firewood is in our assumptions $6.9 \mathrm{GJ}$ per m3 which corresponds to the figure used by Kander (2002). Kander (2017) also adjusted Schön's estimates of firewood consumption (Kander 2002) based on new estimates of the iron industry fuel consumption in 1870 and 1913. This is an adjustment of the total series, while, our series is a completely new estimate based on the annual iron production, as well as estimates of charcoal and firewood consumption for the other manufacturing sectors. While Kander does not make any adjustments prior to 1850, we have used Svidén's (1996) figures for further adjustments also for this period. There are also some additional differences worth to mention. Kander is using figures for the charcoal consumptions per ton of iron which are smaller than Arpi's stated figures. While Arpi is claiming $166 \mathrm{hl}$ (solid)/ton bar iron in 1875, Kander is assuming $115 \mathrm{hl}$ (solid)/ton wrought iron in 1870. On the other hand Kander is using a figure for the firewood consumption in the charcoal manufacturing process which are clearly higher than the Swedish one's stated by Arpi (1951) and Klason (1919). Figure 1 shows the three different estimates of firewood and charcoal consumption in the manufacturing industry.

Figure 1. Estimates of firewood and charcoal in Swedish manufacturing industry 1800 to 1913 . PJ

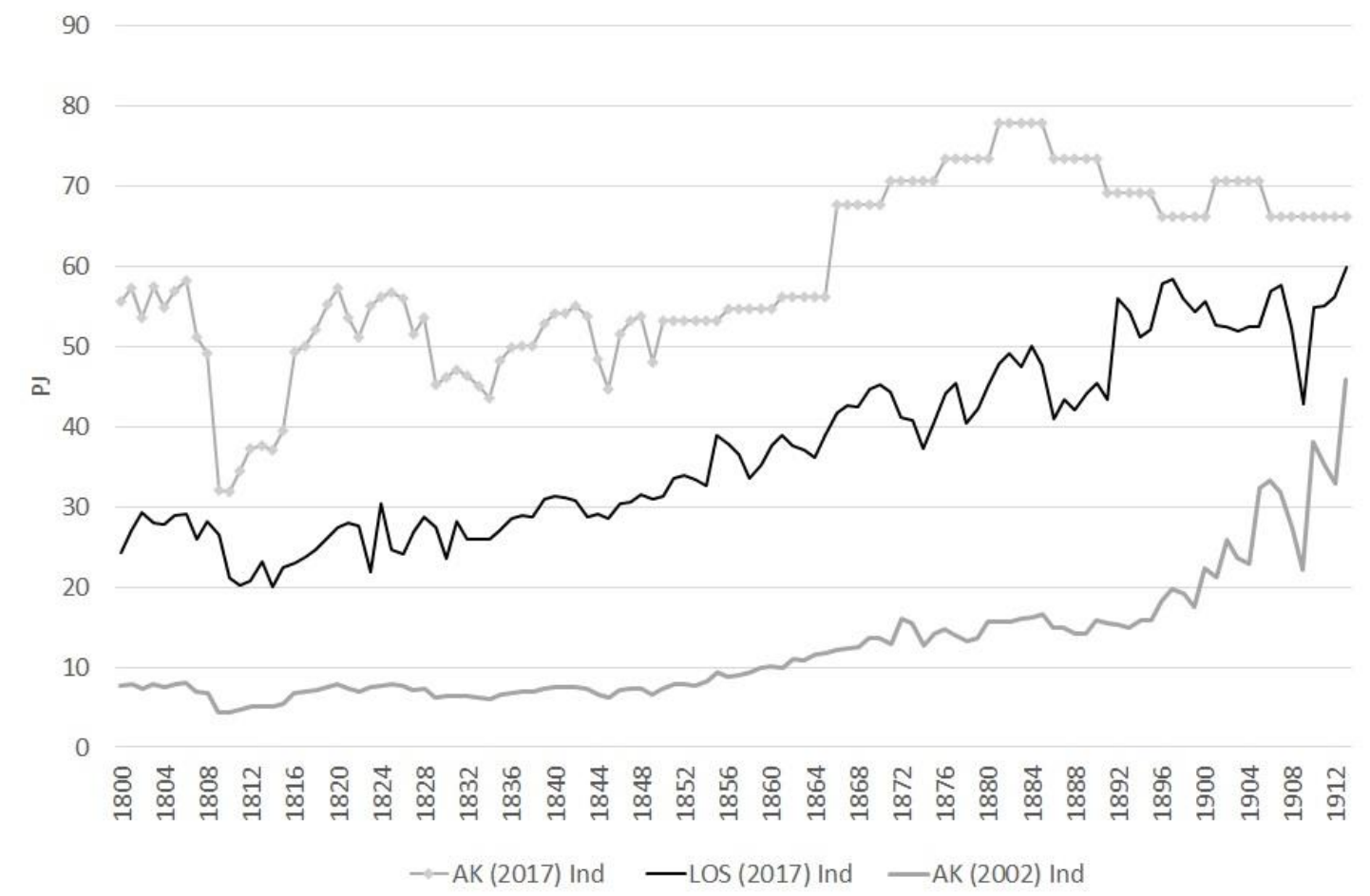

Note: AK (2002) is Schön's series published in Kander (2002); AK (2017) is the adjusted series by Kander in Kander et al (2017), LOS (2017) is estimates presented in this article

Both Kander's 2017 series (AK 2017) and the series presented in this article (LOS 2017) implies significant upward adjustments of the energy consumption in the manufacturing industry as 
compared to the estimate from 2002. The series presented here is, however, lower than AK 2017 and also reveals a different development, which clearly seen in the figure.

\subsection{Mechanical hydropower}

Even though mechanical hydropower was a comparatively small energy source in quantitative terms (see Kander 2002 p. 50), it was a strategically important energy source in nineteenth century iron manufacturing (Eriksson 1955). Previous estimates includes a bench mark estimated for 1896 (Kander 2002) and a back cast by Henriques \& Borowiecki (2017). In the estimates parented in the present study we have foremost focused on tracing the developments in certain manufacturing sectors such as saw mills in which mechanical hydropower was important. Installed mechanical hydropower for direct use in the iron industry amounted to $57,000 \mathrm{Hp}$ when annual figures were first published in the official statistics in 1892. For estimating the development up to 1892 we have used a back-cast approach, using the indexed iron output to estimate the development of motive hydropower. Secondly, we have adjusted this estimate with the volume of iron output per day, which almost doubled over the period 1800 to 1892 (Eriksson 1955, p.162). Accordingly, we estimated the Horsepower Hours $(\mathrm{HpH})$ per day, reflecting our assumption that a higher daily iron production probably meant that the machinery was operated more intensively on a daily basis. Finally, to arrive at the total $\mathrm{HpH}$ we multiplied the $\mathrm{HpH}$ per day with the number of operating days in the iron huts (Eriksson 1955). Transformation from $\mathrm{HpH}$ to Peta Joule (PJ) was done with an appropriate conversion factor. Thus, the calculation used was the following: PJ = (Index Output x Hp 1892 x Index output/days $x$ days $\times 24$ ) C

While charcoal was almost exclusively used in the iron industry, mechanical hydro power was more widely diffused among various sectors in manufacturing. The sawmill industry utilized mechanical hydropower for direct use and, from the last decade of the 19th century, also for the propulsion of electrical generators. Statistics on the installed mechanical hydropower in the sawmill industry was first included in the official statistics from 1896. When reconstructing the energy consumption from mechanical hydropower it is important to consider that hydro powered saw mills were not operated on a full year basis due to ice conditions, which restricted both the timber floatation, the hydro power supply and the shipping of sawn products. On basis of historical company records Sven Gaunitz has suggested a four month period of operation for this type of mill (Bunte et al 1982). Assuming a four month period of operation, we estimate the number of $\mathrm{HpH}$, which in turn are transformed to PJ using the same approach as for the iron works. To estimate the historical development of installed mechanical hydropower we have indexed Gaunitz' estimate of the sawmill industry's timber consumption for the period 1800 to 1896 for a back-cast (Lundgren 1984, p. 223). A potential problem by doing so is that steam power may have substituted for hydro power during the second half of the nineteenth century. In order to evaluate this potential bias, we notice that the installed steam power in the saw mill industry increased from 26.000 to $56.000 \mathrm{Hp}$ over the period 1896 to 1910, while the mechanical hydropower remained fairly constant. Since also the timber consumption remained fairly constant between 1896 and 1910, we assume that the steam engines did not replace mechanical hydro power in absolute terms, but that they rather contributed to higher labor productivity. We therefore concluded it to be fairly safe to use of timber consumption as the main indicator of utilized mechanical hydropower in the saw mill industry prior to 1896 . Also the installed motive hydropower for other industries than iron and saw mills were published in the official statistics from 1896 amounting to $132,370 \mathrm{Hp}$. Here we have indexed the manufacturing industry Value Added (VA) excluding iron manufacturing and saw mills for back-casting the motive power (Schön 1988). The iron industry VA was estimated assuming the same ratio of value added to 
gross output in the sector 'Mining, metal and engineering industry' (Krantz \& Schön 2007) and by estimating the sector's gross output without the volume of iron output. We also assumed that the number of days during which the machinery was operated equaled that of the iron industry. Thus, we estimated the number of $\mathrm{HpH}$ which in turn was transformed to PJ.

\subsection{Tar and potash production}

Tar exports were first estimated in the National Income project ( $\mathrm{NI}$ ) for the period 1870 and onwards (Lindahl et al 1937, p. 202). The exports during the period 1800 to 1870 has been estimated by Lennart Schön (1988, p.88). Since Schön's estimate for 1870 was somewhat higher than the estimate in $\mathrm{NI}$, we have adjusted the $\mathrm{NI}$ series to match Schön's estimate. By doing so we have arrived at a production series in current prices. Secondly, we have calculated the production volume in hectoliters (hl) by deflating the production quantities with Jörberg's tar price series (Jörberg 1972, p. 697). The hectoliter measure was transformed to tons, assuming a density of tar of $100 \mathrm{~kg} / \mathrm{hl}$. The wood consumption in tar production was collected from a study by Sandberg et al (1995), which stated that $37.5 \mathrm{~m} 3$ of wood was required per ton of tar, which the total firewood consumption in the tar production for exports. The estimate is likely to be downward biased since we could not account for tar production for domestic use. The development of Swedish potash production has been estimated by Ekstrand (1893) presented as estimates for a number of benchmark years and, in some cases, period averages. Based on these benchmarks we have used linear interpolation for obtaining annual figures. The firewood requirement has been estimated at two $\mathrm{m} 3$ per kilo of potash has been assumed for the whole period, which makes the estimate of the energy consumption rather straight forward. By the 1890s the potash production had nearly ceased.

\subsection{Coal}

The total domestic use of coal was estimated by Astrid Kander (2002). Kander also estimated a sectoral distribution of coal consumption for 1850 and 1870, which included transportation, agriculture and industry and finally households, including services (Kander 2002 p. 196-203). For the purpose of the present study it is, however, important to separate between final consumption of coal in households and intermediate consumption of coal in manufacturing, gasworks and transports on an annual basis. There are no reliable data on the demand for coal divided on sectors and uses prior to 1913 (Kommerskollegium 1918). Our division therefore departures from the 1913 bench-mark, which provides data on the coal consumption. Besides presenting the data on a fairly disaggregated level, the 1913 investigation also reports the use of various fuels from a technical point of view. It is clear that steam boilers, in practice steam engines, were almost exclusively fired with coal, while charcoal still dominated the fuel consumption at metallurgical furnaces. This motivates indexing data on installed motive power in the manufacturing industry for back-casting the coal consumption in manufacturing. We have chosen to leave the raw motive-power data as reported in the official statistics without any adjustments, thus avoiding interference with the results due to interpolation and unambiguous assumptions. The approach does, however, imply that the effects of the inclusion of new sectors to the statistics affect the results in a step-wise manner. We have, however, taken into account that coal was not used in iron manufacturing furnaces until the turn of the century (Attman 1986, pp 40-41). This implies a sharp increase in the iron manufacturing coal series during the period 1900 to 1913 due to linear interpolation where we assume zero coal use in 1899, linking it to the first official data in 1908 The coal consumption in gasworks has been estimated directly by using data obtained from NI and Lennart Schön (1988, p.55; 89). Coal consumption at the railways was from 1866 obtained directly from the official statistics, while back-casts for the period 1855 to 1866 were based on the transport work volumes estimated by Olle Krantz (1986). Maritime consumption was also made on the basis of the 1913 investigation, which separates between 
domestic and foreign bunker fuels, and by indexing the transport work by steam ship presented by Krantz (1986) for back-casting. The difference between the total coal supply and the estimates series for manufacturing, gasworks and the transport sector shows, in line with Kander results, that the residual, including domestic heating, constituted a large proportion of the total coal consumption in the period up to 1870 . For the period up to 1890 it fell to around 30 percent and further down to between 20 to 25 percent in 1913. This means, in short, that we can claim that coal was strongly associated with the mechanization of manufacturing and transports, but also that household coal consumption probably developed roughly in line with the coal consumption in manufacturing from approximately the 1870s. This result that will be further discussed later in the article.

\section{The development of energy consumption}

The new estimates of energy consumption in the manufacturing industry are expected to lead to an upward adjustment of the estimates originally made by Lennart Schön (1990) and published by Kander (2002); AK-2002. To facilitate the comparison between the new, LOS-2017 series and previously published figures we have calculated a new aggregated series including the sum of new estimates traditional primary energy supply to manufacturing (thus not including coal), household and service sector firewood consumption, coal, petroleum and electricity. This series is in turn comparable with the primary energy supply according to Kander, excluding energy provided by human labor and drought animals. Please notice that the exclusion of human labor and drought animals is not reflecting any idea that these forms of energy were unimportant, but rather that they are not necessary for the comparison. Figure 2 shows that the energy consumption according to the new aggregated series were approximately 20 percent higher than the AK 2002 series but around 25 percent lower than the AK 2017 series, in the beginning of the period. It is also clear that all series are converging at the end of the investigated period.

Figure 2. Total primary energy in Sweden 1800-1913 excluding draught animals and human labor. New and old estimates. PJ

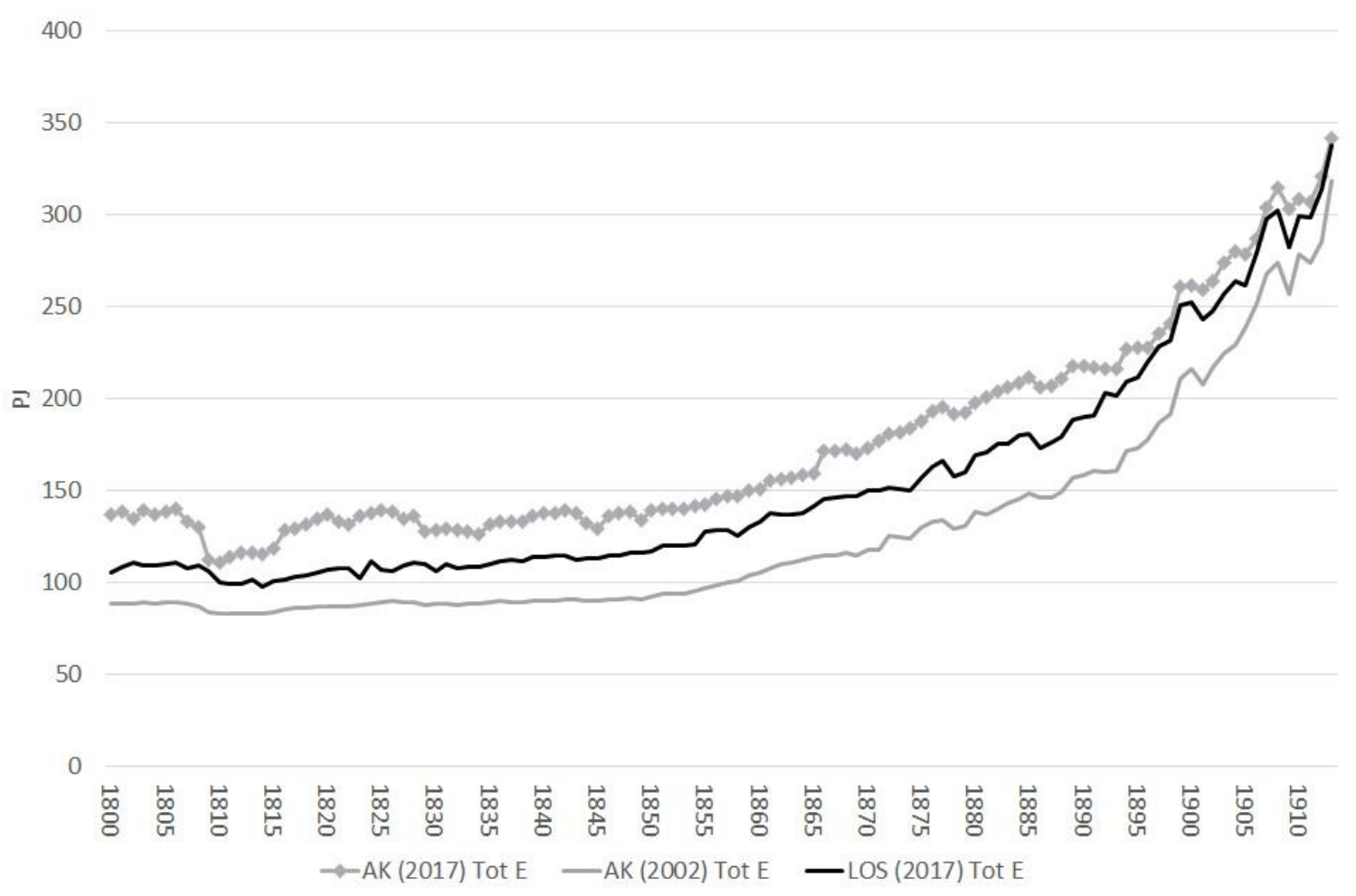


Source: own estimates, Kander (2002), Kander et al (2017)

As growth rates are concerned, the new series, henceforth LOS 2017, grows at similar rates as compared to AK 2017 until approximately 1890, followed by a period of convergence as the new series starts growing at a faster rate. In comparison the 2002-series starts converging to the new series (LOS 2017) around 1900. The overall conclusion is therefore that the new estimates affect the levels of energy consumption, but also that the growth rates differs over the whole period with AK 2017 growing at 150 percent, AK 2002 at 260 percent and LOS-2017 at 220 percent. As GDP seven folded over the period (Krantz \& Schön 2007) an overall conclusion is that the general results concerning a the falling energy intensity reported in Kander (2002) and Kander et al (2017) remain intact even though the revision of the energy consumption in the manufacturing industry reveals noteworthy differences in comparison with the previous series.

\section{Changes in the mix of energy carriers in manufacturing}

The iron industry dominated the energy consumption during the 1800's. It was only in the 1860's that the traditional energy carriers started to increase in industries other than the iron industry, which in turn coincided with a stagnation in the iron industry charcoal consumption.

These matching events, in turn, point at a relationship between ongoing structural changes within the manufacturing sector during the Swedish industrialization, and structural changes pertaining to energy. Given that energy had a limiting effect on economic growth in the manner suggested by Tony Wrigley, it is possible that the stagnating energy consumption in the iron industry was a prerequisite for an increasing energy consumption in other types of manufacturing. Such an explanation would be compatible with a stagnating total consumption of traditional energy carriers. Figure 3 , which shows the energy consumption after energy carrier, demonstrates that the total consumption of traditional energy carriers, where firewood and charcoal was dominating, continued to increase until the 1890s. From 1890 and onwards it is obviously coal that explains the increase of energy consumption. 
Figure 3. Energy consumption after energy carrier in Swedish manufacturing and charcoal production 1800-1913. PJ.

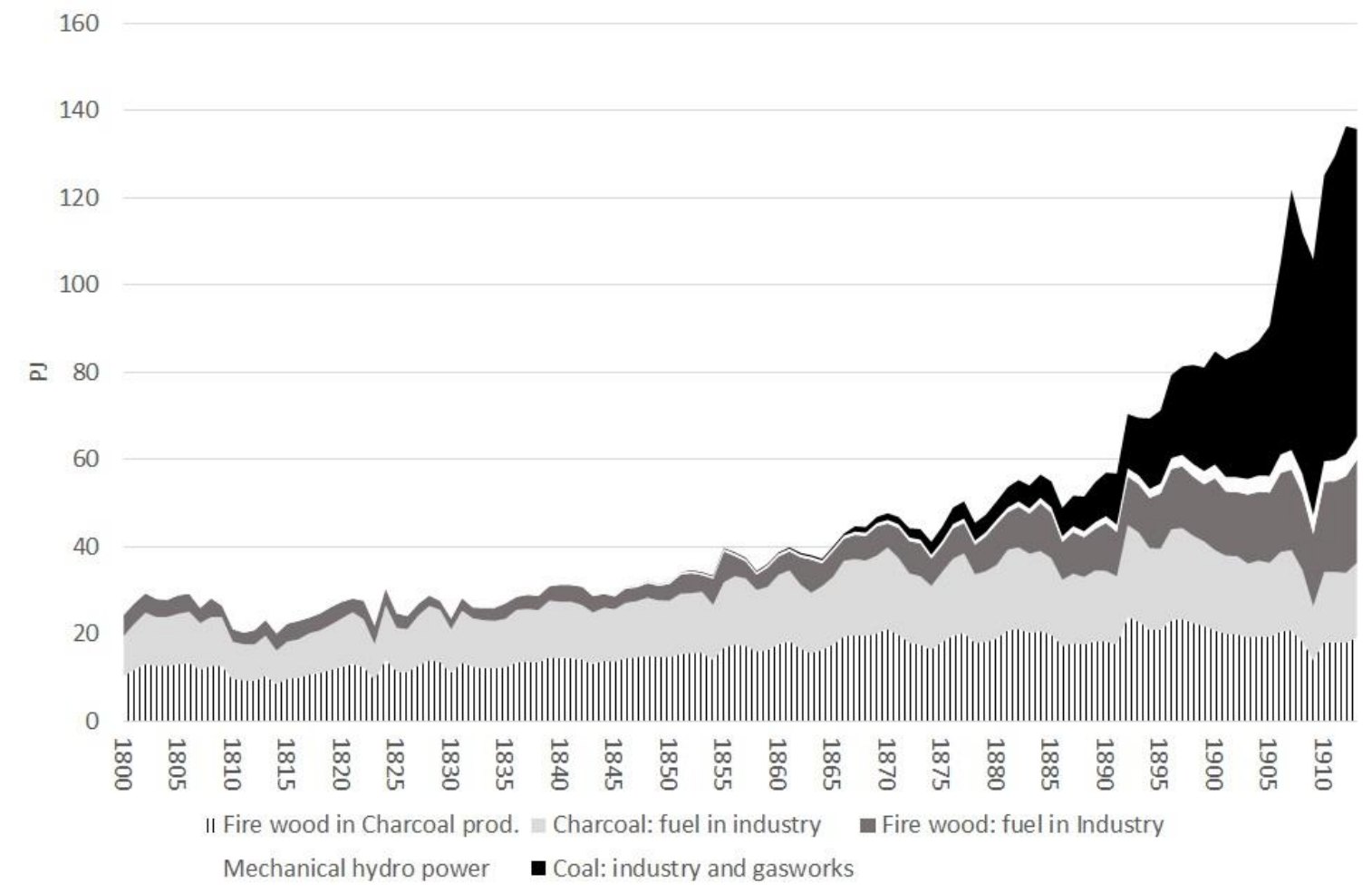

Source: own estimates

To interpret these developments it is necessary to pay attention to the historical context of the Swedish industrialization, starting with the developments in the central Swedish iron industry. The stagnation in iron manufacturing was the result of the stiffer foreign competition. As the foreign output of iron and steel manufactured in coke fired furnaces, prices fell, meaning that the Swedish iron industries faced increasing difficulties in keeping up profits, resulting, on the one hand in stagnating output volumes (Heckscher 1941, p. 284; Attman 1986, pp. 9-30), and on the other hand in technical change, foremost the adaptation of the Martin and Bessemer processes, which resulted in a higher energy productivity (Attman 1986, pp 31-40; Edström 2004). As the firewood and charcoal consumption stagnated in both the metal industries and in tar manufacturing, the energy consumption increased in foremost the forest industries. The sawmill industry's use of firewood and sawdust for fueling boilers increased rapidly during the period 1870 to 1890 (Wik 1950), followed by a rapidly increasing use of firewood in the pulp and paper industries from the early 1890s and onwards. The forest industry was mainly established along the norrlandish coast, utilizing the previously untapped forest resources of inland Norrland, where timber floatation networks linked the logging areas to the coast. In short, we can conclude that the struggling iron industry and the expanding forest industry were not competing over the same restricted organic energy resources. The iron industry was found in central Sweden while the forest industry was mainly situated in Northern Sweden with a center in Sundsvall. Tony Wrigley's idea that the organic energy system posed limits to growth could very well have been true in the central Swedish iron districts, while, at the same time, the restriction was overcome in Northern Sweden. In closing section of this article we 
will discuss why untapped traditional energy resources existed in northern Sweden during a period when organic energy supply assumingly hindered economic growth.

Before we continue to discuss what can be seen as a northern Swedish industrialization in the organic energy system, it is necessary to look closer into the role of coal in the Swedish 19th century economy. One side of this issue is a thought provoking article by Greg Clarke and David Jacks (Clark \& Jacks 2007) were they suggested a counterfactual scenario in which Britain is industrializing with imported Baltic and Scandinavian firewood. Indirectly, this counterfactual can be interpreted as if coal played a minor role in the Swedish industrialization, since the hypothetical possibility to export firewood might as well have substituted for coal imports. Jan Kunnas and Timo Myllyntaus have also proposed that the Finnish industrialization was more or less entirely based on firewood (Kunnas \& Myllyntaus 2009). On a national level it is already from the outset clear that this was not the case in Sweden, even though the share of coal in the total energy supply was smaller than in countries such as Britain, Germany and France (Kander et al 2013, p. 137). Still, looking only at the aggregates may confuse the analysis of energy in the Swedish industrialization. Figure 3 shows that the coal consumption in the manufacturing industry was negligible prior to the 1860 and that the substantial increase only came in the 1890. This is well in line with Kander's (2002. p. 196-202) benchmark estimates for 1850, 1870 and 1913. Taken together, these periods fits rather neatly with the general chronology of the Swedish industrialization as it has been interpreted by scholars such as Eli $F$ Hechscher, Lennart Jörberg, Lennart Schön and Lars Magnusson. A first period has been discerned from 1840 to 1870 , including the first hesitant steps towards industrialization with a first wave of establishment of sawmills and textile industry. This phase coincides with an increase of traditional energy carriers and can as such be seen as evidence for industrialization within the organic energy system. A second phase of industrialization followed in the period 1870 to 1890 , this time characterized by the development of a more diverse industrial structure. The period represented in energy terms the first hesitant period of coal driven growth as the consumption of coal increased faster than it did for traditional energy carriers. The latter were, however, still growing, but at a slow pace, meaning that it is still relevant to talk about industrialization within an organic energy system during the period 1870 to 1890 . As will be argued later on the increased use of coal was significant since coal developed in tandem with steam powered mechanization of both manufacturing and transports. Coal therefore added an important qualitative side to the industrialization. As steam engines allowed more sectors to mechanize, coal contributed significantly to the rise of a diversified industrial structure. For the period after 1890 it is evident from figure 3 that the growth of traditional energy carriers stagnates, while coal increases at a rate which ensured a steady long-term total energy rate. This shift coincides with the industrialization break-through in Sweden, characterized by the emergence of high and sustained economic growth rates. However, before we can continue the analysis it is necessary to discuss some methodological constrains pertaining to coal and the mechanization of manufacturing.

In the estimates presented in the article, the coal series reflects the mechanization of manufacturing not only at a conceptual level, but unfortunately also as a consequence of the method, which is using installed indexed motive power for back-casting the 1913 bench-mark for coal consumption. An implication of the back-casting procedure is a risk that the results are biased by the method itself. In order to partly control for such a bias, we estimated the residual of total coal consumption and the total coal consumption in the manufacturing and the transport and communications sectors. This residual, which can be assumed to reflect the coal consumption in the residential sector, becomes increasingly smaller over time, implying that that most of the growth of the coal consumption can be explained as a consequence of the diffusion of steam engines in the manufacturing and the transport and communications sectors. Since the causality between mechanization and coal consumption is 
straightforward, installed motive power is a measure of the physical work per time unit available for the propulsion of machinery, and since the coal consumption in the residential sector was small as late as 1913, this is evidence for a robust result. Studies in which energy has been used as an indicator can be noticed in the context of these findings, which supports Rubio et al's (2009) use of modern energy as an indicator of modernization in Latin America. Coal consumption in Sweden was closely associated with mechanization through steam engines. As evident from figure 4 , the coal consumption was indeed dominated by the manufacturing and transport sectors, while the consumption in other sectors, including domestic heating and lighthouses, and by definition an error term, was considerably smaller.

Figure 4. Coal consumption after sector. Sweden 1800 to 1913. Tons of primary coal and coke.

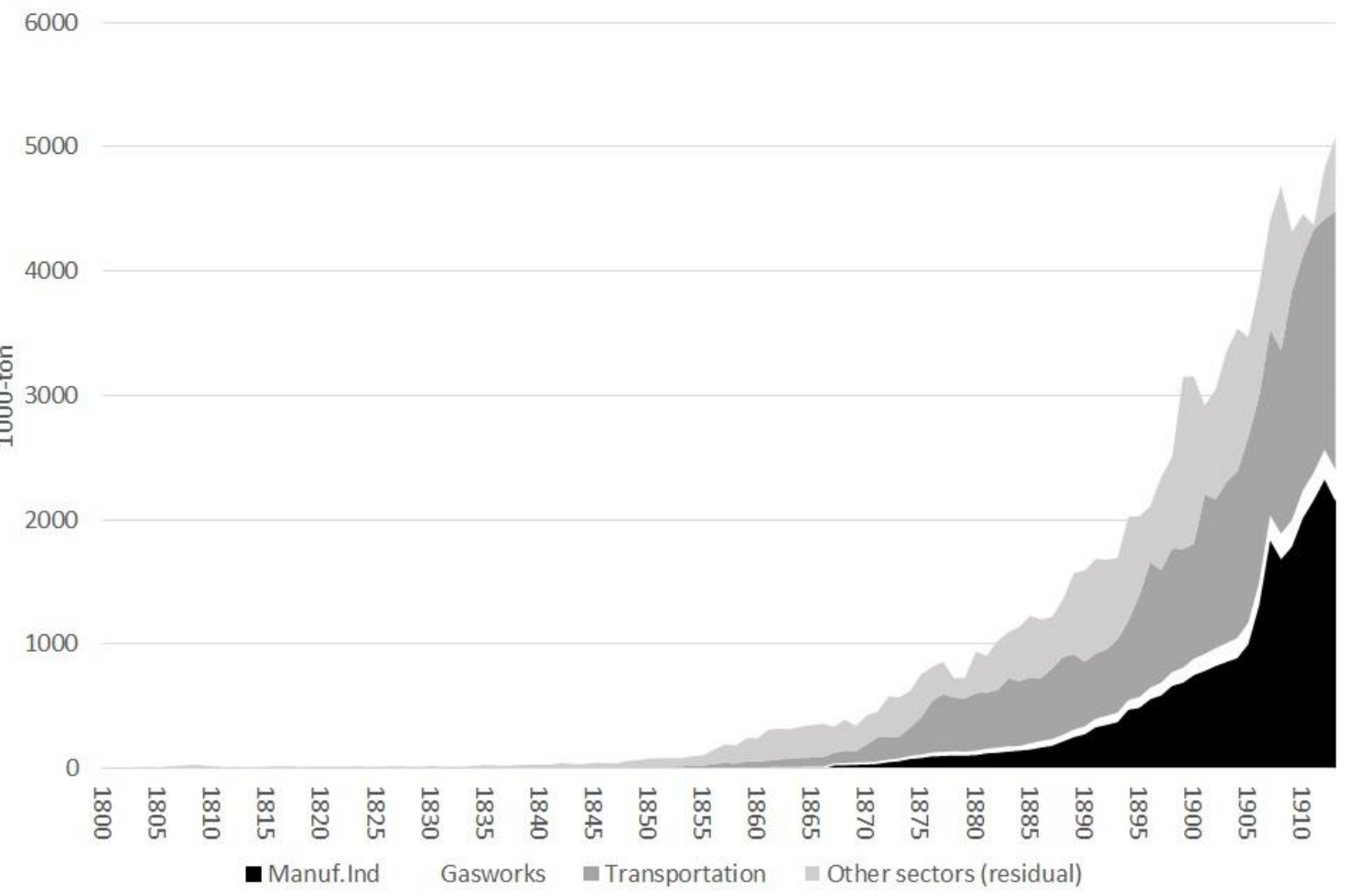

Source: own estimates

The introduction of coal in the Swedish economy was, just as it was in almost every country, an important aspect of the industrialization process since coal was so closely associated modern technologies, foremost the steam engine. We will shortly return to discuss the significance of this observation.

\section{The development of energy intensities in manufacturing}

Energy intensity, measured as the ratio between energy consumption and value added in fixed prices is an often used proxy for energy efficiency. Being a partial, inverted single-factor productivity measure, it is important to bear in mind that the energy intensity may be affected by substitution by other factors of production by capital, improved technical efficiency or effects of structural change, occurring when energy intensive subsectors grow at a different rate than energy extensive sectors. Still, the energy intensity provides a useful indication of the general development of energy efficiency. Figure 5 shows the energy intensity in Swedish manufacturing industry 1800 to 1913 
including firewood consumption in charcoal manufacturing, demonstrating that the energy intensity declined from around 0.9 PJ/MSEK to less than 0.1 PJ/MSEK at the end of the period, corresponding to a 90 percent reduction.

Figure 5. Energy intensity in Swedish manufacturing industry 1800-1913. Semi-log scale.

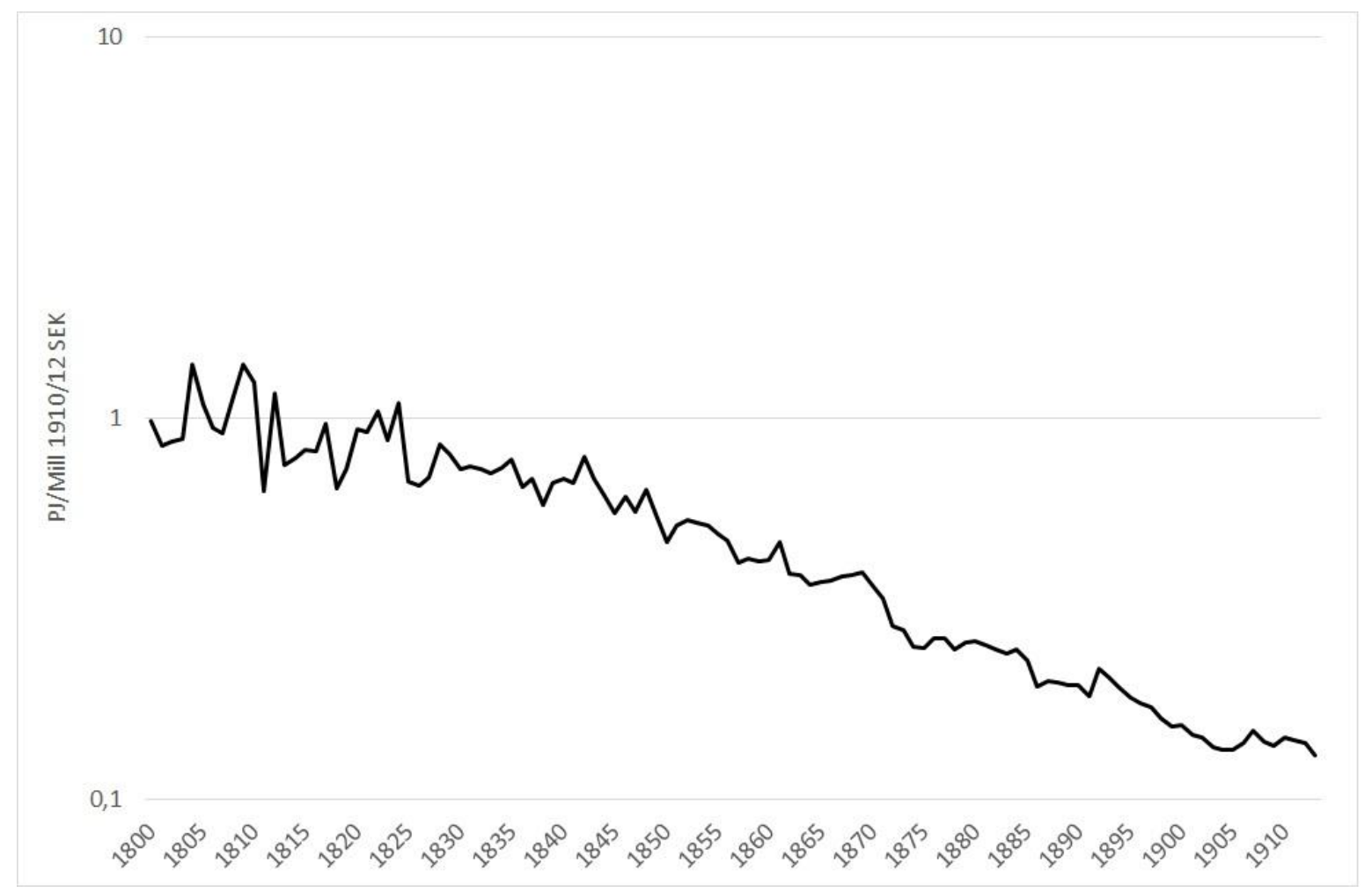

Sources: own estimates. Value added from Krantz \& Schön (2007)

The period 1800 to 1825 hardly reveals any changes in the energy intensity, while there was a slight decrease between 1825 and 1840 . Thereafter the energy intensity fell at an even rate until the end of the investigated period.

Plausible factors behind the decreasing energy intensity includes the previously mentioned developments in iron manufacturing. Since the iron manufacturing consumed the bulk of energy in the Swedish manufacturing industry in the early 1800 s, while its share of industrial output was only around 20 percent, the conclusion can be drawn that the improved fuel efficiency at the iron works, in combination with a lower than average growth rate in iron manufacturing as compared to other industries explains a good part of the declining energy intensity. Indeed, in the counterfactual scenario of no improvements of the energy intensity in the iron industry, in combination with the same value added growth rate as the rest of the industry, the energy intensity only drops to 0.6 $\mathrm{PJ} / \mathrm{MSEK}$ in 1913, corresponding to a 30 percent decrease.

The evidence for a decreasing energy intensity in manufacturing as a characteristic trait of the Swedish industrialization process is important since the development of the energy intensity at the national level is more uncertain. This uncertainty is arises due to the fact that the household sector 
was the largest energy consuming sector, while, at the same time, the historical data on the household energy consumption is particularly weak for the 19th century (Kander 2002; Lindmark \& Andersson 2010). This means that all firewood consumption data for the 19th century are indeed informed guesswork. The first somewhat reliable bench-mark appears as late as 1922 in a special report which also a rough estimate of the geographical per capita firewood consumption in the country (Jonson 1923). When using this bench-mark as a point of departure for back-casting the household firewood consumption during the 19th century, one first needs to consider that the space heating technology improved with the introduction and diffusion of the iron and tile stoves. While the thermal efficiency (how well a stove convert fuel to useful heat) of these technologies is rather well established, their effect on the actual firewood consumption is limited to qualified guesses. Let us first establish that an improved thermal efficiency corresponds to falling relative prices for 'heating'. In other words the amount of firewood needed for heating a certain volume of indoor air to a specific temperature is also the price for heating expressed in firewood. A crucial question is how the households reacted on these relative price changes. In Kander's estimate, the household firewood consumption decreases mainly as an effect of the improvement of heating technology, which is counteracted by an income effect which leads to a demand for more heated rooms. In addition effects from population distribution tends to somewhat increase consumption, while coal substitution reduces firewood consumption. In a hypothetical case when per capita firewood consumption to decrease at a rate proportional to the heating efficiency follows that the price elasticity for per capita heating must be close to zero. If so, the indoor temperatures and the per capita volume of heated space remained fairly constant over the period. The income effect does, however, lead to an increased volume of heated space. If, on the other hand, the price elasticity was close to minus one, technical development led to a more or less proportional increase of indoor temperatures and heated space. In that case, the net effect would have been a rather constant per capita firewood consumption.

It is important to notice that household firewood consumption is an important driver of the aggregated energy intensity in the 19th century. Scrutinizing the back casts is therefore important exactly because the source material remains weak and the impact of the household sector is large. First, it is unlikely that tile stoves had a major impact on the national household firewood consumption. This is because these stoves were used to heat additional rooms apart from the kitchen. This means that even if tile stoves had a much better heat efficiency than the open stoves, tile stoves would have tended to increase the firewood consumption. Exceptions would have been large manors where additional rooms were heated on regular basis and in small urban apartments without cooking facilities. These building types did, however, only represent a minor part of the housing stock and are not likely to have affected the broad developments. It was instead the iron stove that revolutionized domestic space heating and cooking and which, due to its smaller combustion area and heavy iron construction, can be expected to have affected fire wood consumption. The iron stove was, however, only diffused in the late 19th century. It has been reported that open stoves had a heating efficiency of 30 percent (Södergren 2007), while the efficiency of the iron stove probably was around 70 to 80 percent. It is therefore likely that a reduction of the household per capita fire wood consumption took place during the late rather than the early 19th century. However, the iron stove also allowed higher indoor temperatures which interestingly enough suggests that it was the iron stove that motivated double window glassing. A reason for this was, however, that the iron stove did not provide any light which in turn motivated both larger windows led both and to an increased demand for kerosene lamps. It is, however, possible to use the previously estimated coal residual to adjust the Jonson bench-mark for coal substitution, making the assumption that the coal residual primarily captures household coal 
consumption. Thus, we estimate the firewood equivalent of the coal residual. This shows indeed that the per capita firewood consumption from 1840 may have fallen at roughly the same rate as in the estimate by Kander (2002) as an effect of substitution. This result does, however also imply a relatively constant total per capita household energy consumption, suggesting that even if heating technologies where improved during the period, the take-back effect operated through a demand for higher indoor temperatures and more heated space.

Figure 6 illustrates the difference on energy intensity due to assumptions on household firewood on the national energy intensity, showing the AK-2017 energy intensity and the LOS-2017 intensity along with estimates of the household firewood consumption using the coal residual for adjusting household firewood consumption.

Figure 6. Energy intensity 1800-1913 using different assumptions of household energy consumption. Sweden 1800 to 1913. Constant 1910/12 prices.

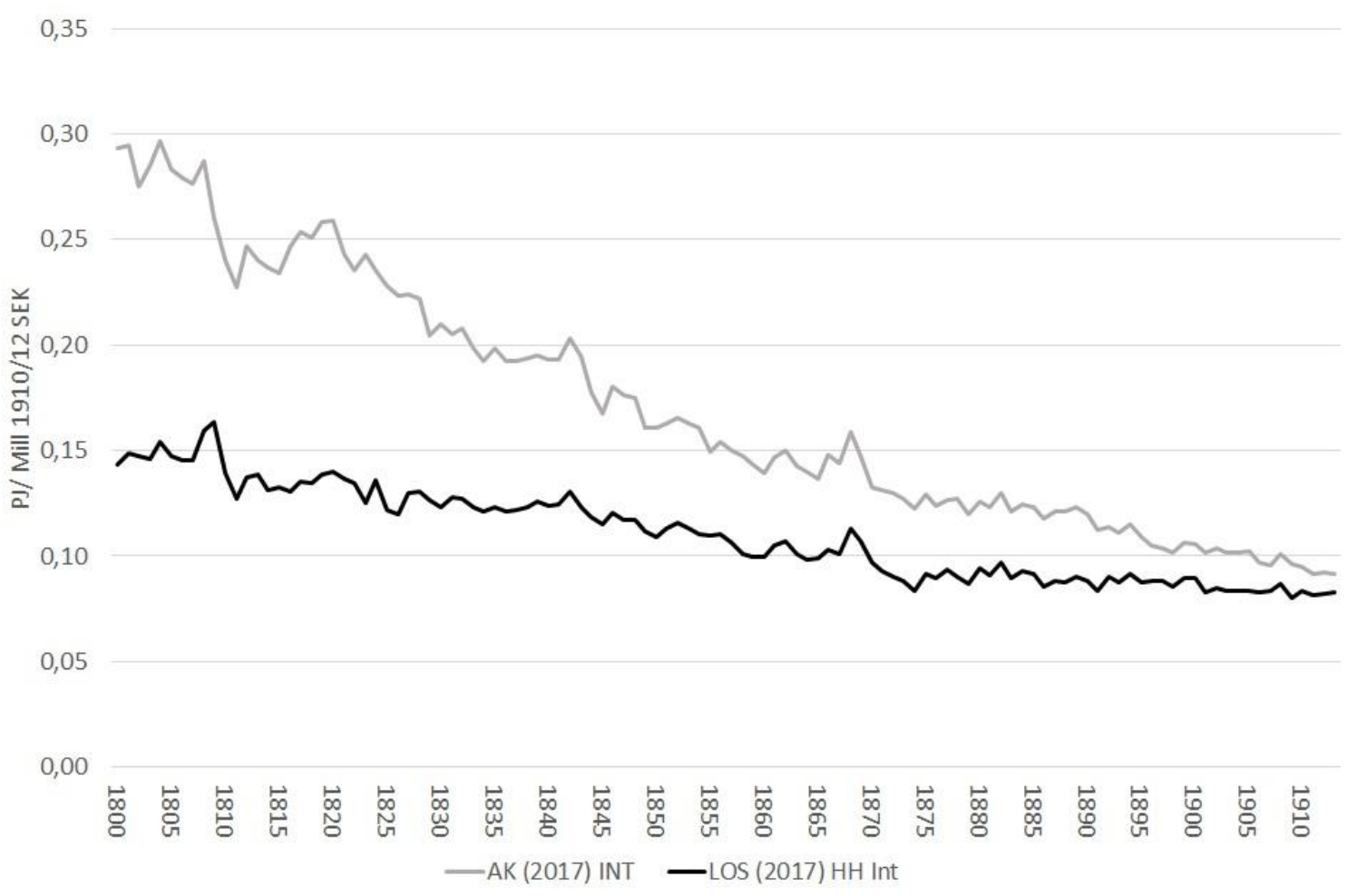

Sources: Own estimates, Kander et al (2017). GDP from Krantz \& Schön (2007)

As evident from figure 6 the LOS-2017 estimate, supplemented with alternative estimates of the household firewood consumption, suggests a much more modest reduction of the energy intensity which even flattens out from approximately 1870. Even if the adjustment of the household firewood consumption is approximative, the exercise shows the importance of revisiting the 19th century household energy consumption by finding either new data sources or means of investigation. Due to the large impact of the household sector and the troublesome data situation, we also suggest that industry level or even micro level studies of the energy transition may be an important way forward for understanding the role of energy in the industrialization process. 
The estimates presented in this study demonstrates a trend of decreasing energy intensity in the manufacturing industry during the period 1800 to 1913 , demonstrating that real energy savings in manufacturing was an integrated part of the Swedish industrialization process. Even though the adjustments are significant in comparison to previous estimates, the new series for the manufacturing industry has a comparatively small impact on the national energy intensity. This is in turn a consequence of the relatively small share of total energy consumption held by manufacturing. It was instead the household sector that mainly determined the development of total energy and thereby the energy intensity during the 19th century. This calls for additional research efforts, since the results to a high degree are driven by assumptions concerning firewood consumption in the household sector, based on a rather poor primary sources. This adds a complicating dimension to energy history as far as the macro level energy intensity is concerned and given that its development is seen as representing a significant as a driver or process in the Swedish industrialization. Since conclusive data support for the 19th century household energy consumption figures largely are missing, an interpretation of the Swedish industrialization process as partly driven my energy saving technology boils down to informed guestimates on the impact of iron and tile stoves on the household firewood consumption. Since the household firewood consumption could have been as high as over four cubic meters solid wood per person and year in the early 1800 s, a sharp reduction in per capita consumption driven by improved household heating technology would have made significant amounts of timber available for alternative uses both as industrial fuels and primary inputs in sawmills and pulp and paper industries. This is in essence a 'tile and iron stove industrialization hypothesis'. This also demonstrates why additional research efforts should be made for understanding the developments of energy consumption in the 19th century. Such research would include both studies of household energy and the diffusion of stoves, as well as industry level and even micro level studies of the energy transition.

In this study we have demonstrated that the transition from the organic to the mineral energy system took place within the sectors traditionally associated with the industrialization in Sweden, namely manufacturing and transportation. While the Swedish industrialization process drew heavily on forest resources and hydro power, fossil fuels seem to have been closely linked to productivity enhancing technology, namely steam engines which from a physical perspective increased the potential physical labor per time unit. As far as there is a strong link between physical labor and utility increasing output, there is also a link between the physical and the economic side of the manufacturing process. Actually, one can argue that the industrialization process must simultaneously have been a physical and an economic process. This is so since the increase of installed effect and use of fossil fuels, characterizing the industrialization process must have been confirmed by the economic system, through prices and returns on investment, in order to have taken place in the first place. The steam engine is both a technical artifact that transform chemical energy to movement, and a unit of capital providing a service flow which translates to profits, capital deepening, rising productivity and real wages. Coal was found at the center of this dual characteristic of the steam engine, providing energy at a reasonable price required for realizing the engine as productive capital.

Even though coal was an integrated part of the industrialization as the preferred fuel for steam engines, forest resources played an important role in the Swedish industrialization process both as a fuel for foremost domestic heating but also as a raw material for the forest industry. At first hand, early 19th century Sweden seemed gifted in terms of organic energy. The potential organic energy per capita was high. Still, the large forest areas in inland northern Sweden were in practice 
economically inaccessible in the beginning of the nineteenth century. Labor was needed to realize the economic potential of these organic resources, which is to say that only if labor could be allocated to logging, the forest would also become an economic resource of any importance. The conditions for agriculture were, however, too poor for sustaining any significant population in inland northern Sweden, which the famines of 1868 and 1869 clearly demonstrated. In short, the new transportation technologies, steamers and railways, which enabled food imports to these regions were needed for the establishment of the labor force required for exploiting the forest resources, including logging and floatation timber to the coast. The paradox is that a good portion of the biofuels and saw timber only became accessible when a partly steam powered transportation system could bring enough food to support a large army of loggers. Interestingly enough this shows how the biological regime limited the access to potential biological resources, and that these biological resources became economic resources through the diffusion of the mineral energy system.

\section{LITTERATURE}

ALLEN, R. C. (2009a). Engels' pause: Technical change, capital accumulation, and inequality in the British industrial revolution. Explorations in Economic History 46, 418-435.

ALLEN, R. C. (2009b). The British Industrial Revolution in Global Perspective. Cambridge: Cambridge University Press.

ALLEN, R. C. (2012). Technology and the great divergence: Global economic development since 1820. Explorations in Economic History 49, 1-16.

ARPI, G. (1951). Den svenska järnhanteringens träkolsförsörjning 1830-1950 [The charcoal consumption in the Swedish iron industry 1830-1950] Jernkontorets Bergshistoriska skriftserie 14, Stockholm: Jernkontoret

ATACK, J., BATEMAN, F. \& MARGO, R.A. (2005) Capital Deepening and the Rise of the Factory: The American Experience during the Nineteenth Century, The Economic History Review 58, 586-595

ATTMAN, A. (1986). Svenskt järn och stål 1800-1914 [Swedish iron and steel 1800-1914] Jernkontorets bergshistoriska skriftserie 21, Stockholm. Jernkontoret

BUNTE, R., GAUNITZ, S. \& BORGEGÅRD, L.-E. (1982). Vindeln: en norrländsk kommuns ekonomiska utveckling 1800-1980; en analys av bondesamhällets ekonomiska utveckling, anpassning och förvandling under 200 år [Vindeln: a Norrlandish municipality's economic development 1800-1980; an analyses of the agrarian society's economic development, adaptation and transformation during 200 years] Lund: Selector

CHRISTENSEN, J.P. (1994) Nogle problemer vedrørande de danske nasjonalregenskabsberegninger i 1800-tallet, Olle Krantz (ed.) Nordiska Historiska Nationalräkenskaper, Occasional Papers in Economic History 1, Umeå: Umeå University

CLARK, G. \& JACKS, D (2007). Coal and the Industrial Revolution, 1700-1869. European Review of Economic History 11, 39-72

CIPOLLA, C.M. (1962). The Economic History of World Population. Harmondsworth: Penguin. 
CRAFTS, N. (2010). Explaining the Industrial Revolution: Two Views. European Review of Economic History 15, 135-168.

ERIKSSON, G. (1955). Bruksdöden i Bergslagen efter 1850. Med särskild hänsyn till företag i Kolbäcksåns dalgång [The iron plant death in Bergslagen after 1850. With special attention to companies in the Kolbäcksån valley] Jernkontorets Bergshistoriska Skriftserie 15, Stockholm: Jernkontoret

EDSTRÖM, J.-O. (2004). Svensk järn- och stålmetallurgi genom tiderna - allmän översikt från 1850 och framåt [Swedish iron and steel metallurgy through the ages] In: BERG, B. (ed.), Järn- och stålframställning. Utveckling i Sverige 1850-2000, Vol. II, Jernkontrorets Bergshistoriska skriftserie 41, Stockholm: Jernkontoret

EKSTRAND, Å.G. (1893). Salpeterindustrin i Sverige [The potash industry in Sweden], Kemisk Tidskrift 5, 24-25; 61-69; 82-86

FRITZ, M. (1972), Den äldre svenska järnexporten [The older swedish iron export], Stockholm: Jernkontoret.

GALES, B., KANDER, A., MALANIMA, P. \& RUBIO, M. (2007). North versus South: Energy transition and energy intensity in Europe over 200 years. European Review of Economic History 11: 219-253

HECKSCHER, E. F. (1941). Svenskt arbete och liv. Från medeltiden till nutid, Stockholm: Albert Bonniers förlag

HILDEBRAND, K.-G. (1992). Swedish Iron in the Seventeenth and Eighteenth Centuries. Export Industry before the Industrialization, Jernkontorets Bergshistoriska Skriftserie 29, Stockholm: Jernkontoret

ISACSON, M. (1998). Bergskollegium och den tidigindustriella järnhanteringen [The Swedish Board of Mines and the early modern iron industry], Daedalus: Tekniska museets årsbok. Stockholm: Tekniska museet

JONSON, T. (1923). De nordiska ländernas skogsproduktion och dess framtida utvecklingslinjer [The forest production in the Nordic countries and its future development] Skogen 21, 241-263

JÖRBERG, L. (1972). A History of Prices in Sweden 1732-1914, Vol. 1, Lund: CWK Gleerup

KANDELL, L. (1988) "Skogsvårdens uppkomst", K. Skogs. o. Lantbr. Akad. Tidskrift, 127, pp. 163-181

KANDER, A. (2002). Economic growth, energy consumption and CO2 emissions in Sweden 1800-2000 (diss.), Lund Studies in Economic History 19, Stockholm: Almqvist \& Wicksell.

KANDER, A. \& STERN, D. (2014) Economic growth and the transition from traditional to modern energy in Sweden, Energy Economics 46, 56-65.

KANDER, A. (2013) Appendix A. In: KANDER, A., MALANIMA, P. \& WARDE, P. (2013). Power to the People: Energy in Europe over the Last Five Centuries. Princeton: Princeton University Press.

KANDER, A., MALANIMA, P. \& WARDE, P. (2013). Power to the People: Energy in Europe over the Last Five Centuries. Princeton: Princeton University Press.

KANDER, A., WARDE, P., TEIVES HENRIQUES, S., NIELSEN, H., KULIONIS, V. \& HAGEN, S. (2017). International Trade and Energy Intensity During European Industrialization, 1870-1935, Ecological Economics 139, 33-44 
KLASON, P. (1919). "Kolning och torrdestillation av ved och därvid framställbara produkter" [Coaling and dry distillation of wood and thereby producible products], Skogsvårdsföreningens tidskrift 17, 125-172.

Kommerskollegium (1918). Bränsleförbrukningen åren 1913-1917 vid industriella anläggningar, kommunikationsanstalter samt allmänna verk och inrättningar. Specialundersökning av kommerskollegium. [Special Inquirery by the National Board of Commerce. Energy Consumption at Industrial Plants, transportation and public buildings for the years 1913-1917]. Stockholm: Kommerskollegium.

KRANTZ, O. (1986). Historiska nationalräkenskaper för Sverige. 4, Transporter och kommunikationer 1800-1980, Lund: Ekonomisk-historiska föreningen

KRANTZ, O., SCHÖN, L (2007), Swedish Historical National Accounts 1800-2000, Lund Studies in Economic History 41, Lund.

KUNNAS, J., McLAUGHLIN, E., HANLEY, N., GREASLEY, D., OXLEY, L. \& WARDE, P. (2014). Counting carbon: historic emissions from fossil fuels, long-run measures of sustainable development and carbon debt. Scandinavian Economic History Review 62, 243-265

KUNNAS, J. \& MYLLYNTAUS, T. (2009). Postponed Leap in Carbon Dioxide Emissions: The Impact of Energy Efficiency, Fuel Choices, and Industrial Structure on the Finnish Energy Economy 1800-2005. Global Environment 3, 154-189.

LINDAHL, E., DAHLGREN, E. \& KOCK, K. (1937). National Income of Sweden 1861-1930, Part III, Stockholm: Institute for Social Sciences, University of Stockholm

LINDMARK, M. \& ANDERSSON, L. F. (2010). Household Firewood Consumption in Sweden during the Nineteenth Century, Journal of Northern Studies, 14, 55-78

LUNDGREN, N.-G. (1986), Skog för export. Skogsarbete, teknik och försörjning i Lule älvdal 18701970, [Forest for export. Forest labour, technology and provision in the Lule River valley 1870-1970] (Diss.) Umeå studies in Economic History 6, Umeå, Umeå University.

MALANIMA, P. (2016). Energy consumption in England and Italy, 1560-1913. Two pathways toward energy transition. Economic History Review 69, 78-103.

McCLOSKEY, D. (2010). Bourgeois Dignity: Why Economics Can't Explain the Modern World. Chicago: The Chicago University Press.

McCLOSKEY, D. (2016). The great enrichment: a humanistic and social scientific account. Scandinavian Economic History Review 64, 6-18

MOKYR, J. (2009). The Enlightened Economy: An Economic History of Britain 1700-1850. New Haven: Yale University Press.

OLSSON, F. (2007), Järnhanteringens dynamik. Produktion, lokalisering och agglomerationer i Bergslagen och Mellansverige 1368-1910 [Dynamics in the iron manufacturing industry Production. Localization and agglomerations in Bergslagen and Central Sweden 1368-1910] (diss.) Umeå studies in Economic History 35, Umeå, Umeå University.

POMERANZ, K. (2000). The Great Divergence: China, Europe, and the Making of the Modern World Economy. Princeton: Princeton University Press. 
RUBIO, M. D. M., YÁÑEZ, C., FOLCHI, M., \& CARRERAS, A. (2009). Energy as an indicator of modernization in Latin America, 1890-1925. Economic History Review 63, 769-804.

SCHÖN, L. (1988). Historiska nationalräkenskaper för Sverige 2. Industri och Hantverk 1800-1980 [Historical National Accounts for Sweden: Manufacturing and handicrafts 1800-1980] Lund, Ekonomisk-historiska föreningen.

SCHÖN, L. (1990). Elektricitetens betydelse för svensk industriell utveckling. Vattenfall, FUD-rapport 1990:60.

SCHÖN, L. (2000). Electricity, Technological Change and Productivity in Swedish Industry, 1890-1990, European Review of Economic history 4, 175-194

SOU 1923:57. Vid virkesmätning erfoderliga relationstal ['Measuring wood'], Stockholm.

STERN, D., \& KANDER, A. (2012). The Role of Energy in the Industrial Revolution and Modern Economic Growth. The Energy Journal 33, 125-152.

SUNDBERG, U. (1992), Ecological Economics of the Swedish Baltic Empire: an Essay on Energy and Power, 1560-1720, Ecological Economics 5, 51-72.

SVIDÉN, J. (1996). Industrialisering och förändrad miljöpåverkan. Råvaruflöden samt svavel- och kvicksilverutsläpp vid bruk i norra Kalmar län 1655-1920 [Indsutrialization and changing environmental impact. Flows of raw materials and sulphur and mercury emissions at iron plants in northern Kalmar county 1655-1920], diss. Linköping Studies in Arts and Science, Linköping.

SÖDERGREN, D. (2007) Öppna Spisar. Metod som förhindrar öppna spisar att ryka in (Diss.). Institutionen för energiteknik, KTH, Stockholm.

WIESLANDER, G. (1936). Skogsbristen i Sverige under 1600- och 1700-talen [The scarcity of forests in Sweden during the 17th and 18th centuries] Skogsvårdsföreningens tidskrift 34, 593-663

WIK, H. (1950), Norra Sveriges sågverksindustri från 1800-talets mitt till 1937, (diss.), Geographica 21, Uppsala, Uppsala Universitet

WRIGLEY, E. A. (1962). The Supply of Raw Materials in the Industrial Revolution, Economic History Review 15, 1-16.

WRIGLEY, E. A. (1988). Continuity, Chance and Change: The Character of the Industrial Revolution in England. Cambridge: Cambridge University Press.

WRIGLEY, E. A. (2010). Energy and the English Industrial Revolution. Cambridge: Cambridge University Press.

WRIGLEY, E. A. (2016). The Path to Sustained Growth. England's transition from an organic economy to an industrial revolution. Cambridge: Cambridge University Press. 